\title{
Beneficial effects of garlic (Allium sativum) oil in experimental corrosive esophageal burns effects of garlic oil in esophageal burns
}

\author{
Ceren Şen Tanrıkulu, M.D., ${ }^{1}$ Yusuf Tanrikulu, M.D., ${ }^{2}$ Fahriye Kılınç, M.D., ${ }^{3}$ \\ Burak Bahadır, M.D., ${ }^{4}$ Murat Can, M.D., ${ }^{5}$ Füruzan Köktürk, M.D. ${ }^{6}$
}

\author{
${ }^{1}$ Department of Emergency Medicine, Bülent Ecevit University Faculty of Medicine, Zonguldak-Turkey \\ ${ }^{2}$ Department of General Surgery, Zonguldak Atatürk State Hospital, Zonguldak-Turkey \\ ${ }^{3}$ Department of Pathology, Konya Numune Hospital, Konya-Turkey \\ ${ }^{4}$ Department of Pathology, Bülent Ecevit University Faculty of Medicine, Zonguldak-Turkey \\ ${ }^{5}$ Department of Biochemistry, Bülent Ecevit University Faculty of Medicine, Zonguldak-Turkey \\ ${ }^{6}$ Department of Biostatistics, Bülent Ecevit University Faculty of Medicine, Zonguldak-Turkey
}

\begin{abstract}
BACKGROUND: Corrosive esophageal burns, particularly common in developing countries, lead to different problems in different age groups. The ingestion of corrosive substances can cause such problems as stricture of the esophagus, to acute perforation, and even death. Because stricture formation is related to the severity of the initial injury, the prevention of stricture constitutes a main goal of treatment. The aim of this study was to investigate the protective and anti-inflammatory effects of garlic (Allium sativum) oil in corrosive esophageal burn.
\end{abstract}

METHODS: Twenty-eight rats were randomly divided into 4 equal groups: group I (sham), group 2 (control), group 3 (topical treatment), and group 4 (topical and systemic treatment). In groups 2, 3, and 4, corrosive esophageal burns were generated by applying sodium hydroxide to a $1.5-\mathrm{cm}$ segment of the abdominal esophagus. Normal saline was applied to group 2, topical garlic oil to group 3 , and topical and systemic garlic oil were used in group 4.

RESULTS: The level of hydroxyproline was lower in the topical treatment groups than in the control group ( $p=0.023)$. There was difference in tumor necrosis factor alpha level between the systemic treatment groups and the control group ( $p=0.044)$. Treatment with garlic oil decreased stenosis index (SI) and histopathological damage score (HDS) in corrosive esophageal burn rats. The SI in the topical treatment group was significantly lower than that of the control group $(p=0.016)$. The HDS was significantly lower in group 4 when compared with the control group $(p=0.019)$.

CONCLUSION: Garlic oil is an effective agent in promoting the regression of esophageal stenosis and tissue damage caused by corrosive burns. While the protective effect of garlic oil on tissue damage is more significant when applied topically, the anti-inflammatory effect is more pronounced when applied systemically. Therefore, we believe that the application of garlic oil in patients with corrosive esophageal burns can reduce complication rates.

Keywords: Corrosive esophageal burn; garlic oil; hydroxyproline; stenosis index; tumor necrosis factor alpha.

Address for correspondence: Ceren Şen Tanrıkulu, M.D. Konya Eğitim ve Araştırma Hastanesi, Acil Tıp Kliniği, 42100 Konya, Turkey

Tel: +90 505 - 887 I3 87 E-mail: cerensen8I@hotmail.com

Ulus Travma Acil Cerrahi Derg

2017;23(3): $181-187$

doi: $10.5505 /$ tjtes.2016.64509

Copyright 2017

TJTES

\section{INTRODUCTION}

Corrosive esophageal burns are quite common leading to different problems in different age groups. Corrosive substances are accidentally ingested by children and purposely by adults. [1] Alkaline substances are easily accessible because they are commonly used for cleaning, soap making, and fruit drying; $90 \%$ of the corrosive esophageal burn cases are caused by alkaline substances. ${ }^{[2,3]}$

The severity of gastrointestinal tract damage depends on the 
concentration, amount, and physical form (solid or liquid) of the ingested substance and the duration of contact with the mucosa. ${ }^{[4]}$ The ingestion of corrosive substances can cause issues such as stricture of the esophagus, acute perforation, and even death. ${ }^{[5]}$

The aims of corrosive esophageal burn treatment are to improve wound healing, prevent perforation, and reduce stricture formation. Stricture formation is correlated with the severity of the initial injury and is a significant problem in corrosive esophageal burns. Therefore, preventing stricture formation is the main goal in most of the treatments. ${ }^{[6-8]} \mathrm{Ad}-$ ditionally, because stricture formation consists of fibrosis and inflammation during the wound healing process, medical treatments should also aim to reduce the inflammation. ${ }^{[9]}$ Although many agents have been used in various studies to prevent the stricture development, antibiotics and steroids have only recently gained clinical approval. ${ }^{[10-13]}$

Garlic oil, a diallyl trisulfide, is the main active constituent of garlic. The beneficial effects of dietary garlic have been known for centuries. To this end, garlic has been used in many different areas of clinical medicine. Furthermore, garlic oil has a wide range of pharmacological properties, such as anticancer, antibacterial, anti-inflammatory, fibrinolytic, wound healing, antioxidant, and antiadhesive activities. ${ }^{[14,15]}$

However, no studies have examined the effects of garlic oil in a corrosive esophageal injury. Herein, we investigate the beneficial effects of garlic oil in corrosive esophageal burns.

\section{MATERIALS AND METHODS}

\section{Study Design and Animals}

All experiments were conducted in accordance with the $\mathrm{Na}$ tional Guidlines for the Use and Care of Labortaory Animals at the Bülent Ecevit University Laboratory for animal experiments after obtaining an approval from the animal ethics committee of Bülent Ecevit University. Twenty-eight male adult Wistar albino rats, weighing $250 \pm 30 \mathrm{~g}$, were individually housed under a constant temperature $\left(2 I \pm I^{\circ} \mathrm{C}\right)$ in wire cages with $12 \mathrm{~h}$ light-dark cycles. The rats were fed a standard diet and water ad libitum. Twelve hours before anesthesia, the animals were deprived of food but had free access to water up to $2 \mathrm{~h}$ before anesthesia. No enteral or parenteral antibiotics were administered at any time.

\section{Experimental Groups}

The animals were randomly divided into four equal groups (seven rats in each group):

Group I (Sham): A corrosive esophageal burn was not created after the laparotomy. A $0.1 \mathrm{~mL}$ dose of saline was intraperitoneally administered to each rat daily for 10 days.

Group 2 (Control): A corrosive esophageal burn was cre- ated after the laparotomy. A $0.1 \mathrm{~mL}$ dose of saline was intraperitoneally administered to each rat daily without any treatment for 10 days.

Group 3 (Topical treatment group): A corrosive esophageal burn was created after the laparotomy. After washing the esophageal lumen with saline, a $5 \mathrm{ml} / \mathrm{kg}$ dose of garlic oil was topically administered to the esophageal lumen. Rats were incubated for $30 \mathrm{~min}$ in a reverse Trendelenburg position to provide sufficient mucosal contact with the drug. Then, a 0.1 $\mathrm{mL}$ dose of saline was intraperitoneally administered to each rat daily for 10 days.

\section{Group 4 (Topical and Systemic treatment group): A} corrosive esophageal burn was created after the laparotomy. After washing the esophageal lumen with saline, a $5 \mathrm{ml} / \mathrm{kg}$ dose of garlic oil was topically administered to the esophageal lumen. Rats were incubated for $30 \mathrm{~min}$ in a reverse Trendelenburg position to provide sufficient mucosal contact with the drug. Then, a $5 \mathrm{ml} / \mathrm{kg}$ dose of garlic oil was intraperitoneally administered to each rat daily for 10 days.

\section{Experimental Model}

The experimental corrosive esophageal burns were formed according to the model described by Gehanno et al. in 1981. ${ }^{[16]}$ Animals were anesthetized by an intramuscular injection of $80 \mathrm{mg} / \mathrm{kg}$ ketamine hydrochloride (Ketalar ${ }^{\circledR}$, Parke-Davis, Istanbul, Turkey) and $20 \mathrm{mg} / \mathrm{kg}$ xylazine (Rompun ${ }^{\circledR}$, Bayer, Istanbul, Turkey). In this study, a I.5-cm distal esophageal segment was used. Following a median laparotomy, a 5-Fr catheter was passed through the mouth and placed into the distal esophagus. To prevent escape directly into the stomach and respiratory tract by aspiration, the cardioesophageal junction and proximal esophagus were tied with $2 / 0$ silk. Then, 0.1 $\mathrm{mL}$ of $37.5 \%$ sodium hydroxide $(\mathrm{NaOH})$ solution were administered for $90 \mathrm{~s}$ and aspirated. Subsequently, the burned segment was washed with distilled water for $30 \mathrm{~s}$. Catheters were withdrawn by cutting the sutures, and the gastric insertion site was repaired. Following closure of the laparotomy, $10 \mathrm{~mL} 0.9 \%$ saline were intraperitoneally administered, and the rats were fasted for the next $24 \mathrm{~h}$. The treatment of the study groups was started from the first postoperative day. The rats were fed standard food and water ad libitum in standard laboratory conditions during the treatment period.

\section{Histopathological Evaluation}

HDS and SI were chosen as methods of evaluation. All specimens were evaluated and scored by a single pathologist blinded to the study groups. For the histopathological evaluation, $2-\mathrm{cm}$ distal esophageal sections were taken. The esophageal tissue samples were fixed in 10\% neutral formaldehyde. Fixed tissue samples were routinely embedded using the paraffin embedding technique. Then, $5-\mu \mathrm{m}$ thick tissue samples were taken and stained with hematoxylin-eosin (H\&E) and Masson's trichrome (MT) to evaluate changes in the ligament tis- 
sue. Tissues were scored in three categories for a total score of $0-5$ (Table I). ${ }^{[17]}$ For the SI evaluation, the esophageal wall thickness and luminal diameters were measured using a millimetric ocular microscope (Olympus BX53, Tokyo, Japan). For the $\mathrm{SI}$ calculation, the averages of the measurements taken from four different locations by two pathologists were used. SI was calculated as follows: $\mathrm{SI}=$ [wall thickness $(\mathrm{AI}+\mathrm{A} 2) / 2] /$ [lumen diameter $(\mathrm{BI}+\mathrm{B} 2) / 2] \cdot{ }^{[18]}$

\section{Biochemical Analysis}

Tissue hydroxyproline concentrations were determined using the spectrophotometric method of Bergman and Loxley. ${ }^{[19]}$ The results were expressed as micrograms of hydroxyproline per milligram of tissue $(\mu g / \mathrm{mg})$.

Rat TNF- $\alpha$ levels were detected in the serum by a rat TNF- $\alpha$ ELISA kit (Eastbiopharm, Hangzhou, China). Briefly, samples, standards, and streptavidin-HRP were added into the plate wells of the kit. Antibodies were labeled with enzyme, and the plate was incubated for $60 \mathrm{~m}$ at $37^{\circ} \mathrm{C}$. Then, the plate was washed five times and chromogen solutions were added. Subsequently, the plate was further incubated for $10 \mathrm{~min}$ at $37^{\circ} \mathrm{C}$ before the stop solution was added into the wells. The optical density (OD) of each well was measured at $450 \mathrm{~nm}$ with a microplate reader. The corresponding sample OD values were calculated from a linear regression of a set of standards to determine the corresponding sample concentration.

\section{Statistical Analysis}

Data were analyzed using the SPSS (Statistical Package for Social Science) for Windows 19.0 package program. Data normality was tested using a one-sample Kolmogorov-Smirnov test. Continuous variables were reported as means \pm standard deviation and were compared using Kruskal-Wallis variance analyses. Dunn's test was used for post hoc tests after the Kruskal-Wallis test. Noncontinuous variables were reported as medians (min-max) and were compared using the ChiSquare test. $P$ values of $<0.05$ were considered statistically significant.

\section{RESULTS}

The comparison levels of hydroxyproline and TNF- $\alpha$ among the groups are summarized in Table 2 . The levels of hydroxyproline were significantly lower in group 3 than in group 2 $(p=0.023)$. Based on the TNF- $\alpha$ levels, there was no difference between group 2 and group 3. The TNF- $\alpha$ level was significantly lower in group 4 than in group $2(p=0.044)$. There were no differences among the treatment groups for hydroxyproline and TNF- $\alpha$ levels $(p=1.000)$.

The comparisons of esophageal stenosis among the groups are summarized in Table 3. There was no difference among the groups based on the lumen diameters $(p=0.920)$. The wall thicknesses in the treatments groups were lower than that in group 2. According to the wall thickness, there was a significant difference between group 3 and group $2(p=0.047)$, whereas there was no significant difference between group 4 and group $2(p=0 . \mid 5 I)$. According to $S I$, there was a significant difference between group 3 and group $2(p=0.016)$.

The comparisons of histopathological evaluations among the groups are summarized Table 3 and Figure I. HDS was selected as the method of evaluation (Table I). The sham group generally showed normal histologic state with slight increase in the submucosal collagen. Other groups showed variable number of inflammatory cells in the esophagus wall with characterized reactions. The control group showed an increase in the submucosal connective tissue, collagen in tunica muscularis, and esophagus wall thickness $(p=0.043)$. Increase of submucosal collagen was still active, but the deposition of collagen in muscularis mucosa was way less than the control group. In accordance with these results, the total HDS were

Table I. Histopathological evaluation criteria

\begin{tabular}{lc}
\hline Criteria & Score \\
\hline Increase in submucosal collagen & 0 \\
None & I \\
Mild (submucosal collagen at least twice the thickness of muscularis mucosa) & 2 \\
$\quad$ Severe (submucosal collagen more than twice the thickness of muscularis mucosa) & I \\
Damage to the muscularis mucosa & 2 \\
None & 0 \\
Present & I \\
Damage and collagen deposition in tunica muscularis & 2 \\
$\quad$ Mild (collagen deposition around the smooth muscle fibers) & \\
Severe (same as mild with collagen deposition replacing some muscle fibers) &
\end{tabular}


Table 2. Comparisons of hydroxyproline and TNF- $\alpha$ among groups

\begin{tabular}{lcc}
\hline Groups & Hydroxyproline $(\mu \mathrm{g} / \mathrm{mg})$ & TNF- $\alpha$ \\
\cline { 2 - 3 } & \multicolumn{1}{c}{ Mean \pm SD } & Mean \pm SD \\
\hline Group I (SHAM) & $0.73 \pm 0.18$ & $24.65 \pm 9.24$ \\
Group 2 (control) & $3.14 \pm 0.52$ & $53.92 \pm 8.87$ \\
Group 3 (topical treatment) & $1.37 \pm 0.46^{\mathrm{a}}$ & $44.61 \pm 13.18$ \\
Group 4 (topical+systemic treatment) & $1.77 \pm 0.19$ & $39.80 \pm 15.16^{\mathrm{b}}$ \\
\hline${ }^{\mathrm{a}} \mathrm{p}=0.023,{ }^{\mathrm{b}} \mathrm{p}=0.044$ vs. group 2. & &
\end{tabular}

Table 3. Comparisons of histopathological evaluation among groups

\begin{tabular}{|c|c|c|c|}
\hline \multirow[t]{2}{*}{ Groups } & \multirow{2}{*}{$\frac{\begin{array}{c}\text { Wall } \\
\text { thickness }(\mu \mathrm{m})\end{array}}{\text { Mean } \pm \text { SD }}$} & \multirow{2}{*}{$\begin{array}{c}\begin{array}{c}\text { Stenosis } \\
\text { index }\end{array} \\
\text { Mean } \pm S D\end{array}$} & \multirow[t]{2}{*}{$\begin{array}{l}\text { Total histopathologic } \\
\text { score }\end{array}$} \\
\hline & & & \\
\hline Group I (SHAM) & $0.72 \pm 0.22$ & $0.4 I \pm 0.1 I$ & $0(0-I)$ \\
\hline Group 2 (control) & $1.21 \pm 0.1 \mathrm{I}$ & $0.73 \pm 0.21$ & $3(1-3)$ \\
\hline Group 3 (topical treatment) & $0.73 \pm 0.17^{\mathrm{a}}$ & $0.43 \pm 0.05^{b}$ & $2(I-2)^{\#}$ \\
\hline Group 4 (topical+systemic treatment) & $0.91 \pm 0.33$ & $0.5 I \pm 0.18$ & $I(I-2)^{*}$ \\
\hline
\end{tabular}

significantly lower in the treatment groups than in group 2 ( $p=0.026$, group $3 ; p=0.033$, group 4$)$.

\section{DISCUSSION}

Despite many experimental and clinical studies, no effective and safe agent other than steroids has been identified for the treatment of corrosive esophageal burns. While garlic oil has been used effectively in many areas of medicine, no studies have investigated its effects in a corrosive esophageal injury. This study revealed the beneficial effect of garlic oil in corrosive esophageal burns.

The ingestion of caustic substances is a serious problem because these substances cause corrosive esophagitis in the acute necrotic phase and stricture formation in the long-term. Therefore, the key to coping with these complications is to understand the pathophysiology. The level of damage differs depending on the type of tissue; the amount, type (acid and alkali) and physical structure (solid or liquid) of the caustic substance; and the duration of contact. ${ }^{[4]}$ While ingestion of alkaline substances causes liquefaction necrosis in esophageal mucosa and submucosa, in severe cases, acidic substances cause coagulation necrosis in the muscularis mucosae layer. [20] Acute necrotic phase is seen over the first I- 4 days and is characterized by decreased tissue perfusion, increased lipid peroxidation, hydrolysis, reactive oxygen radicals, and beginning of inflammation. Following the subacute phase and long-term period, the scar formation begins with fibroblast proliferation. The stricture formation occurs via collagen accumulation. $^{[12,20]}$

The main goal of any medical treatment is to reduce any inflammation because the severity of the acute inflammatory reaction plays the most significant role in stricture formation. [21] The current treatment protocols in corrosive esophagitis remain limited to antibiotics and steroids administration and neutralizations during the acute phase. There are many treatment methods that vary according to the phase and severity of damage. ${ }^{[9]}$ To reduce inflammation and collagen synthesis and to prevent fibroplasia and stricture formation, many clinical and experimental studies have evaluated the medical efficiency of antioxidant and anti-inflammatory agents, such as sucralfate, palifermin, dimethyl sulfoxide, prednisolon, retinoic acid, zinc, trapidil, trimetazidine, and pentoxifylline. ${ }^{[9-13,20,21]}$ Despite decreased stricture formations in these studies, the rate of stricture formation remained at $70 \%-100 \%$ in highgrade corrosive esophagitis. ${ }^{[9]}$

Garlic oil, a diallyl trisulfide, is the main active constituent of garlic and is one of the oldest medicine. Garlic oil has diverse biological properties, including anticarcinogenic, antibacterial, anti-inflammatory, fibrinolytic, wound healing, antioxidant, and antiadhesive activities. ${ }^{[14,22]}$

Studies have indicated that garlic oil shows an anti-inflammatory effect by reducing the production of IL2, ILI2, IL6, 

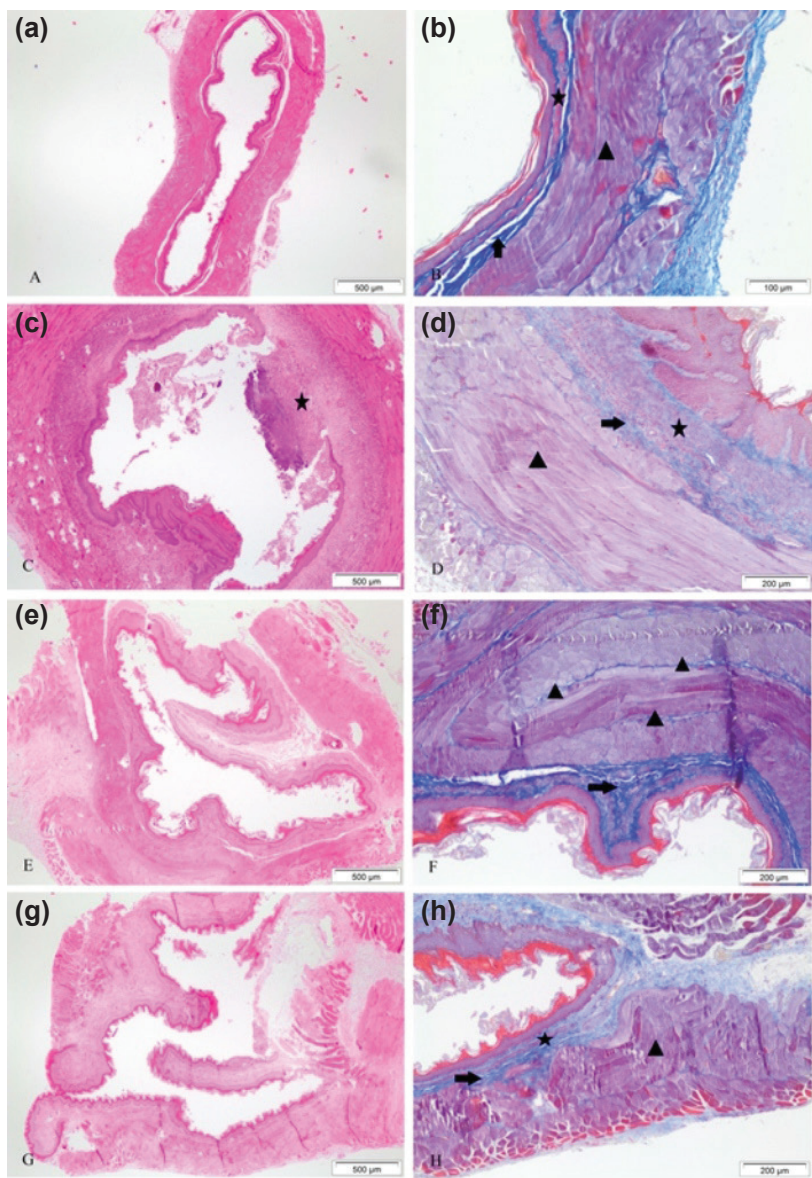

Figure 1. The sham group appears to have normal esophagus histology with a slight increase in the submucosal collagen $(\mathbf{a}, \mathbf{b})$ The control group show no apparent increase in the lumen diameter, but has a thicker wall and contains focal inflammatory cells that raise the epithelium in comparison to the sham group (markedly with star) (c). Muscularis mucosa and tunica muscularis are thickened, also the submucosal collagen is slightly increased (d). Topically treatment group (Group 3) has evident differences in the lumen diameter when compared to the sham and control group. The wall thickness is more significant compared to the sham group and less prominent compared to the control group (e). Submucosa and muscularis tunica store minimal amounts of collagen (f). Systemically treatment group (Group 4) does not show an apparent difference in the lumen diameter in comparison to other groups; the increase in wall thickness is more compared to the sham group, less compared to the control group, and close to the topically treatment group (g). Submucosa shows a slight rise in the collagen, muscularis mucosa shows no increase in thickness, and tunica muscularis shows a bit of increase in thickness with no damage or rise in collagen (h). In the Masson Trichrome figures, the star represents the muscularis mucosal layer, the arrow represents the submucosal layer, and the triangle represents the tunica muscularis. For A, C, E, and G; B; and D,F, and H, H\&E with X40 magnification, MT with magnification $\times 200$, and MT with magnification $\times 100$, respectively, were used.

IL8, and TNF- $\alpha$ and by increasing the production of IL I0. ${ }^{[23,24]}$ Keiss et al., ${ }^{[25]}$ showed that garlic oil reduced the activation of NFKB and the production of ILI $\beta$ and TNF- $\alpha$. Chang et al., ${ }^{[26]}$ found that garlic oil showed anti-inflammatory effects in suppressing the production of nitric oxide (NO) and prostaglandin E2 in activated macrophages.

The antioxidant activity of garlic oil is primarily dependent on sulfur-containing compounds. This activity is higher in aged garlic extracts. ${ }^{[22]}$ Nencini et al.," ${ }^{[2]}$ found that fresh Allium homogenates possess antioxidant properties. Park et al., ${ }^{[28]}$ further described the antioxidant activities of garlic extracts. Additionally, garlic oil has broad-spectrum antibacterial effects, and its antibacterial mechanism may be related to the growth inhibition of bacteria by sulfur-containing compounds in garlic. ${ }^{[14]}$

In a randomized retrospective study conducted by Gümüldülü et al., ${ }^{\left[{ }^{9]}\right.}$ the prevalence of stricture formation was shown to be reducible with sucralfate treatment. Howell et al., ${ }^{[29]}$ found that the steroidal treatment of corrosive esophagitis decreased the frequency of stricture formation. Aciksari et al., ${ }^{[13]}$ compared the treatment effects of beta-aminopropionitrile (BAPN) and prednisolone and found that BAPN was better able to decrease the development of stenosis and tissue damage than prednisolone. In another study, ${ }^{[21]}$ dimethyl sulfoxide was observed to reduce acute phase symptoms and to decrease the severity of tissue damage. Apart from inflammation, oxidative stress is believed to play an important role in increasing tissue damage. Günel et al., ${ }^{\left[{ }^{30]}\right.}$ found that reactive oxygen radicals increased during the early phase of esophageal burns. In another study, Ocakci et al., ${ }^{[17]}$ showed that $\mathrm{NaOH}$ treatment increased lipid peroxidation. In corrosive esophageal burns, while SI and HDS are the most important indicators of esophageal damage, the hydroxyproline level is an indicator collagen accumulation. These indicators are used to demonstrate esophageal strictures and to evaluate the efficacy of therapeutic agents. ${ }^{\left[{ }^{\prime \prime}\right]}$ In our study, we examined SI and HDS to evaluate esophageal damage, the levels of hydroxyproline to evaluate the collagen accumulation, and the levels of TNF- $\alpha$ to evaluate anti-inflammatory effects. We found that the levels of TNF- $\alpha$ were significantly lower in the systemic treatment groups than in the control group. However, the levels of hydroxyproline were significantly lower in the topical treatment groups than in the control group. Additionally, there was a difference in SI between group 3 and the control group $(p=0.016)$. In terms of histopathological results, the total histopathological damage scores were significantly lower in the treatments groups than in group 2 $(p=0.026$, group $3 ; p=0.033$, group 4$)$.

\section{Conclusion}

We found that the topical or systemic administrations of garlic oil were effective in regressing esophageal stenosis and tissue damage caused by corrosive burns. This effect was more pronounced in the systemic treatment. While the effect of garlic oil on tissue damage was more significant when topically applied, the anti-inflammatory effect was more pro- 
nounced in systemic applications. We believe that the application of garlic oil during the initial treatment of emergency clinic patients with corrosive esophageal burns can reduce the complication rates of stenosis and strictures. However, to further assess the effectiveness of garlic oil applications, comprehensive clinical studies are required.

\section{Ethical Approval \\ None.}

\section{Conflict of interest: None declared.}

\section{REFERENCES}

1. Karaoglu AO, Ozutemiz O, Ilter T, Batur Y, Yonetci N, Tekesin O, et al. Caustic ingestion injuries: evaluation of 108 cases. Turk J Gastroenterol 1998;9:55-60.

2. Bautista A, Varela R, Villanueva A, Estevez E, Tojo R, Cadranel S.E f fects of prednisolone and dexamethasone in children with alkali burns of the oesophagus. Eur J Pediatr Surg 1996;6:198-203. [CrossRef]

3. Millar AJW and Cywes S. Caustic strictures of esophagus. In: Pediatric Surgery. O'Neill JJ, Rowe MI, Grosfeld JL, et al (eds). St Louis: Mosby 1998. p. 969-79.

4. Peters JH, De Meester TR. Esophagus and diaphragmatic hernia. Schwartz SI, Shires GT, Spencer FC (Ed). Principles of Surgery. Seventh ed. New York: McGraw-Hill 1999. p. 1158-61.

5. Ekingen G, Ozden M, Sözübir S, Maral H, Müezzinoğlu B, Kahraman $\mathrm{H}$, et al. Effect of the prostacyclin derivate iloprost in experimental caustic esophageal burn. Pediatr Surg Int 2005;21:441-4. [CrossRef]

6. Koltuksuz U, Mutuş HM, Kutlu R, Ozyurt H, Cetin S, Karaman A, et al. Effects of caffeic acid phenethyl ester and epidermal growth factor on the development of caustic esophageal stricture in rats. J Pediatr Surg 2001;36:1504-9. [CrossRef]

7. Cakmak M, Nayci A, Renda N, Erekul S, Gökçora H, Yücesan S. The effect of corticosteroids and pentoxifylline in caustic esophageal burns. A prospective trial in rats. Int Surg 1997;82:371-5.

8. Demirbilek S, Bernay F, Rizalar R, Bariş S, Gürses N. Effects of estradiol and progesterone on the synthesis of collagen in corrosive esophageal burns in rats. J Pediatr Surg 1994;29:1425-8. [CrossRef]

9. Gümürdülü Y, Karakoç E, Kara B, Taşdoğan BE, Parsak CK, Sakman G. The efficiency of sucralfate in corrosive esophagitis: a randomized, prospective study. Turk J Gastroenterol 2010;21:7-11. [CrossRef]

10. Corduk N, Koltuksuz U, Calli-Demirkan N, Rota S, Abban G, Sarioglu-Buke A. Effects of retinoic acid and zinc on the treatment of caustic esophageal burns. Pediatr Surg Int 2010;26:619-24. [CrossRef]

11. Caliskan C, Bolukbasi H, Firat O, Yeniay L, Ozutemiz O, Korkut MA. Stricture-prevention effects of pentoxifylline and trimetazidine in an experimental corrosive esophagitis model. Akademik Gastroenteroloji Dergisi 2009;8:6-11.

12. Somuncu S, Cakmak M, Erdogan S, Caglayan O, Akman H, Kaya M. Trapidil, an inhibitor for phosphodiesterase and platelet-derived-growth factor, ameliorates corrosive esophageal burn in rats. Tohoku J Exp Med
2005;207:203-8. [CrossRef]

13. Aciksari K, Yanar HT, Hepgul G, Ozucelik DN, Yanar F, Agcaoglu O, et al. The effect of Beta-aminopropionitrile and prednisolone on the prevention of fibrosis in alkali esophageal burns: an experimental study. Gastroenterol Res Pract 2013;2013:574260. [CrossRef]

14. Guo Y. Experimental study on the optimization of extraction process of garlic oil and its antibacterial effects. Afr J Tradit Complement Altern Med 2014;11:411-4. [CrossRef]

15. Schäfer G, Kaschula CH. The immunomodulation and anti-inflammatory effects of garlic organosulfur compounds in cancer chemoprevention. Anticancer Agents Med Chem 2014;14:233-40. [CrossRef]

16. Gehanno P, Guedon C. Inhibition of experimental esophageal lye strictures by penicillamine. Arch Otolaryngol 1981;107:145-7. [CrossRef]

17. Ocakci A, Coskun O, Tumkaya L, Kanter M, Gurel A, Hosnuter M, et al. Beneficial effects of Ebselen on corrosive esophageal burns of rats. Int J Pediatr Otorhinolaryngol 2006;70:45-52. [CrossRef]

18. Berthet B, di Costanzo J, Arnaud C, Choux R, Assadourian R. Influence of epidermal growth factor and interferon gamma on healing of oesophageal corrosive burns in the rat. Br J Surg 1994;81:395-8. [CrossRef]

19. Bergman RL. Two improved and simplified methods for the spectrophotometric determination of OH-proline. Anal Chem 1963;35:1961-5.

20. Numanoğlu KV, Tatli D, Bektaș S, Er E. Efficacy of keratinocyte growth factor (palifermin) for the treatment of caustic esophageal burns. Exp Ther Med 2014;8:1087-91. [CrossRef]

21. Kilincaslan $\mathrm{H}, \mathrm{Ozbey} \mathrm{H}, \mathrm{Olgac} \mathrm{V}$. The effects of dimethyl sulfoxide on the acute phase of experimental acid and alkali corrosive esophageal burns. Eur Rev Med Pharmacol Sci 2013;17:2571-7.

22. Capasso A. Antioxidant action and therapeutic efficacy of Allium sativum L. Molecules 2013;18:690-700. [CrossRef]

23. Hodge G, Hodge S, Han P. Allium sativum (garlic) suppresses leukocyte inflammatory cytokine production in vitro: potential therapeutic use in the treatment of inflammatory bowel disease. Cytometry 2002;48:20915. [CrossRef]

24. Chang HP, Huang SY, Chen YH. Modulation of cytokine secretion by garlic oil derivatives is associated with suppressed nitric oxide production in stimulated macrophages. J Agric Food Chem 2005;53:2530-4. [CrossRef]

25. Keiss HP, Dirsch VM, Hartung T, Haffner T, Trueman L, Auger J, et al. Garlic (Allium sativum L.) modulates cytokine expression in lipopolysaccharide-activated human blood thereby inhibiting NF-kappaB activity. J Nutr 2003;133:2171-5.

26. Chang HP, Chen YH. Differential effects of organosulfur compounds from garlic oil on nitric oxide and prostaglandin E2 in stimulated macrophages. Nutrition 2005;21:530-6. [CrossRef]

27. Nencini C, Franchi GG, Cavallo F, Micheli L. Protective effect of Allium neapolitanum Cyr. versus Allium sativum L. on acute ethanol-induced oxidative stress in rat liver. J Med Food 2010;13:329-35. [CrossRef]

28. Park JH, Park YK, Park E. Antioxidative and antigenotoxic effects of garlic (Allium sativum L.) prepared by different processing methods. Plant Foods Hum Nutr 2009;64:244-9. [CrossRef]

29. Howell JM, Dalsey WC, Hartsell FW, Butzin CA. Steroids for the treatment of corrosive esophageal injury: a statistical analysis of past studies. Am J Emerg Med 1992;10:421-5. [CrossRef]

30. Günel E, Cağlayan F, Cağlayan O, Akillioğlu I. Reactive oxygen radical levels in caustic esophageal burns. J Pediatr Surg 1999;34:405-7. [CrossRef] 


\section{DENEYSEL ÇALIŞMA - ÖZET}

\section{Deneysel korozif özefagus yanıklarında sarımsak yağının (Allium Sativum) yararlı etkileri}

Dr. Ceren Şen Tanrıkulu, ${ }^{1}$ Dr. Yusuf Tanrikulu, ${ }^{2}$ Dr. Fahriye Kılınç, ${ }^{3}$ Dr. Burak Bahadır, ${ }^{4}$ Dr. Murat Can, ${ }^{5}$ Dr. Füruzan Köktürk ${ }^{6}$

${ }^{1}$ Bülent Ecevit Üniversitesi Tıp Fakültesi, Acil Tıp Anabilim Dalı, Zonguldak

${ }^{2}$ Zonguldak Atatürk Devlet Hastanesi, Genel Cerrahi Kliniği, Zonguldak

${ }^{3}$ Konya Numune Hastanesi, Patoloji Kliniği, Konya

${ }^{4}$ Bülent Ecevit Üniversitesi Tıp Fakültesi, Patoloji Anabilim Dalı, Zonguldak

${ }^{5}$ Bülent Ecevit Üniversitesi Tıp Fakültesi, Biyokimya Anabilim Dalı, Zonguldak

${ }^{6}$ Bülent Ecevit Üniversitesi Tıp Fakültesi, Bioistatistik Anabilim Dalı, Zonguldak

AMAÇ: Özellikle gelişmekte olan ülkelerde daha yaygın görülen korozif özefagus yanıkları farklı yaş gruplarında farklı problemlere yol açarlar. Korozif maddelerin yutulması özefagus striktürlerinden perforasyona hatta ölüme kadar birçok problem neden olabilir. Striktür oluşması ilk hasarın şiddeti ile ilişkili olduğundan striktür gelişiminin önlenmesi tedavinin asıl amacıdır. Bu çalışmada, korozif özefagus yanığında sarımsak yağının (Allium Sativum) koruyucu ve antienflamatuvar etkisi araştııııdı.

GEREÇ VE YÖNTEM: Yirmi sekiz sıçan rastgele dört eşit gruba ayrıldı; I. grup (Sham), 2. grup (kontrol), 3. grup (topikal tedavi) ve 4. grup (topikal ve sistemik tedavi). Sham grubu hariç diğer gruplarda abdominal özefagusun $1.5 \mathrm{~cm}$ 'lik distal kısmına $\mathrm{NaOH}$ uygulanarak korozif özefagus yanı̆̆ı oluşturuldu. İkinci gruba normal salin, 3. gruba topikal sarımsak yağı ve 4. gruba topikal ve sistemik sarımsak yağı verildi.

BULGULAR: Hidroksiprolin seviyeleri topikal tedavi grubunda kontrol grubundan daha düşüktü $(p=0.023)$. Sistemik tedavi grubu ile kontrol grubu arasında tümör nekrozis faktör alfa $(T N F-\alpha)$ seviyelerine göre farklılık mevcuttu $(p=0.044)$. Sarımsak yağı ile tedavinin stenoz indeksini $(S I)$ ve histopatolojik hasar skorunu (HDS) azalttığı görüldü. Kontrol grubu ile karşılaştırıldığında topikal tedavi grubunda SI belirgin olarak daha düşüktü ( $p=0.016)$. Histopatolojik hasar skoru kontrol grubuna göre sistemik tedavi grubunda anlamlı olarak düşüktü $(p=0.019)$.

TARTıŞMA: Sarımsak yağı korozif özefagus yanığına bağlı oluşan doku hasarının ve özefagial stenozun azaltılmasında etkili bir ajandır. Sarımsak yağı topikal uygulandığında doku hasarı üzerine koruyucu etkisi daha belirgin iken, sistemik uygulandığında antienflamatuvar etkilerinin daha ön plandaydı. Bundan dolayı, korozif özefagus yanığı olan hastalarda sarımsak yağı uygulamasının komplikasyon oranlarını azaltacağına inanıyoruz.

Anahtar sözcükler: Hidroksiprolin; korozif özefagus yanığı; sarımsak yağı; stenoz indeksi; TNF- $\alpha$.

Ulus Travma Acil Cerrahi Derg 2017;23(3):181-187 doi: 10.5505/tjtes.2016.64509 